\title{
GERENCIAMENTO DE BACIAS HIDROGRÁFICAS - ESTUDOS DE CASO DA BACIA HIDROGRÁFICA DO RIO IGUAÇU NO MUNICÍPIO DE NOVA IGUAÇU
}

\author{
Watershed management - Case study of the river basin of the Iguaçu River in Nova Iguaçu \\ municipality
}

Alexandre Silva de Miranda

Mestrando na UFRRJ no curso de Geografia alexandre2155@gmail.com

Artigo recebido em 01/05/2016 e aceito para publicação em 20/11/2016

DOI: 10.12957/tamoios.2017.22675

\section{Resumo}

O crescimento urbano das grandes cidades que podemos verificar nas últimas décadas tem posto em alerta a temática da preservação ambiental dos corpos hídricos, como é o caso da Bacia da Baía de Guanabara, com elevado processo de poluição e deterioração. As mazelas ambientais nesta região, dentre outros problemas, comprometem a qualidade de vida dos seus habitantes, efeito este que pode ser constatado pelos parâmetros ambientais apresentados. Esse artigo consiste na regularização de informações sobre as principais intervenções realizadas na Bacia do rio Iguaçu, bem como na sua análise à luz da educação ambiental, visando contribuir para uma gestão integrada a ser implantada nesta bacia. Sugere-se para minimização dos impactos ambientais uma gradativa busca às condições originais da bacia, nos locais em que isso for possível, respeitando-se e valorizando os aspectos naturais das calhas dos afluentes, evitando a ocupação das matas ciliares. Faz-se necessário, pelas instâncias governamentais, o melhor emprego dos recursos financeiros, além do cumprimento da legislação ambiental, do disciplinamento do uso/ocupação do solo, valorizando-se os aspectos naturais da bacia hidrográfica buscando a sustentabilidade ambiental, sendo fundamental a construção de um plano de gerenciamento integrado da bacia e o monitoramento participativo da comunidade envolvida nesse processo.

Palavras-chave: Recursos hídricos; gerenciamento de bacias hidrográficas; bacia hidrográfica do rio Iguaçu; educação ambiental; recuperação de bacias hidrográficas urbanas.

\begin{abstract}
Urban growth of large cities that we can see in recent decades has put on alert the theme of environmental protection of water bodies, such as the Basin of the Bay of Guanabara, with high process pollution and deterioration. Environmental ills in the region, among other problems, compromise the quality of life of its inhabitants, an effect which can be determined by environmental parameters presented. This article is to regularize information on the major interventions in the Iguaçu River Basin, as well as in its analysis in the light of environmental education, to contribute to an integrated management to be implemented in this basin. It is suggested to minimize the environmental impacts a gradual search to the original conditions of the basin, in places where this is possible, respecting and valuing the natural aspects of the gutters of tributaries, avoiding the occupation of riparian forests. It is necessary, by government bodies, the best use of financial resources, in addition to compliance with environmental legislation, the disciplining of use / land use, valuing the natural aspects of the river basin seeking environmental sustainability, it is essential to building an integrated management plan for the basin and participatory monitoring of the community involved in this process.
\end{abstract}

Key-words: Water resources; watershed management; basin of the Iguaçu River; environmental education; recovery of urban watersheds. 


\section{INTRODUÇÃO}

O problema da poluição ambiental urbana já não se restringe apenas à qualidade do ar que respiramos e da água em nossas torneiras. A maioria daqueles que habitam o estado do Rio de Janeiro não sabem os prazeres que os corpos d'água como a baía de Guanabara um dia já proporcionou. É enganoso pensar que o tratamento das águas residuais levará a uma despoluição das áreas contaminadas. A deposição atmosférica, os resíduos sólidos, o esgoto pluvial e o lodo decantado continuarão presentes durante um longo período. Algumas das cidades nos EUA e países desenvolvidos, que obtiveram êxito na coleta e tratamento das águas residuais, segundo novos levantamentos, têm mostrado que as fontes de poluição difusa passaram a ser as maiores causadoras de degradação da qualidade das águas superficiais (DRISCOLL et al. 1990, EPA 1983).

Este artigo irá mostrar uma avaliação quantitativa da poluição gerada pela população que reside ao entorno do rio Iguaçu realizando assim um trabalho de coleta e avaliação da qualidade da água do rio, onde será verificada a questão do saneamento básico, a degradação qualitativa da água, contribuindo assim para o desenvolvimento prático de um trabalho de educação ambiental detalhado e funcional com os moradores que residem ao entorno do recorte utilizado nessa pesquisa, onde será abordado questões como o manejo inadequado dos rejeitos domésticos e industriais in natura neste recurso hídrico tão importante para os moradores da região.

O problema da poluição ambiental urbana já não se restringe apenas à qualidade do ar que respiramos e da água em nossas torneiras. A maioria daqueles que habitam o estado do Rio de Janeiro não sabem os prazeres que os corpos d'água como a baía de Guanabara um dia já proporcionou.

\section{CARACTERIZAÇÃO FÍSICA E SÓCIO ECONÔMICA DA BACIA HIDROGRÁFICA DO RIO IGUAÇU-SARAPUÍ}

A bacia do rio Iguaçu-Sarapuí tem uma área de drenagem que mede $726 \mathrm{Km} 2$, dos quais $168 \mathrm{Km} 2$ representam a sub- bacia do Sarapuí e $558 \mathrm{Km} 2$ a do Iguaçu. Esta bacia abriga parte dos Municípios do Rio de Janeiro, Nilópolis, Mesquita, São João de Meriti, Nova Iguaçu, Belford Roxo e Duque de Caxias, todos inseridos na Região Metropolitana do Rio de Janeiro, conforme demonstra a figura 6. O município de Mesquita, apesar de ter sido desmembrado de Nova Iguaçu no ano de 1999, só foi instalado em 2001, ou seja, um ano após o último censo do IBGE. Por esta razão, na maioria das tabelas são usados os dados mais amplamente divulgados, os do Censo de 2000, que tratam do município de Nova Iguaçu ainda englobando o de Mesquita. Também por este motivo, dependendo do ano da base de dados utilizada para confecção dos mapas, os mesmos apresentam ou não Mesquita já estabelecido como município. 


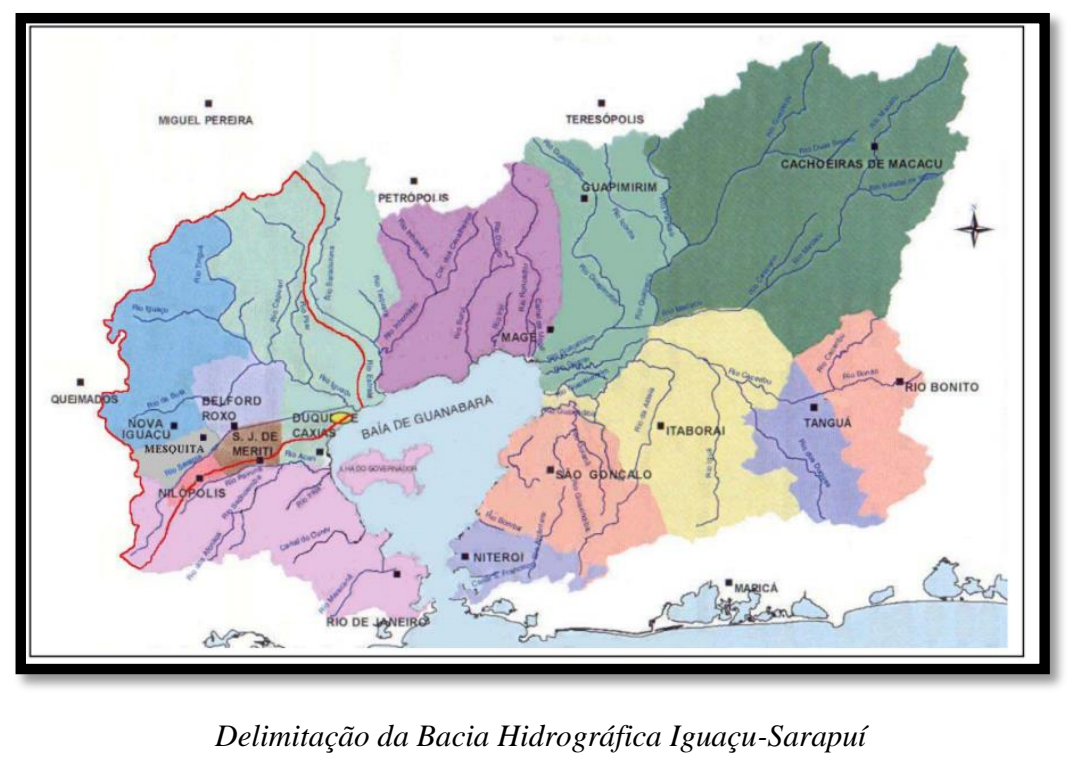

A bacia do rio Iguaçu-Sarapuí limita-se ao norte com a bacia do rio Paraíba do Sul, ao sul com a bacia dos rios Pavuna/Meriti, a leste com a bacia dos rios Inhomirim /Estrela e a oeste com a bacia do Rio Guandu e afluentes da baía de Sepetiba (INSTITUTO BAIA DE GUANABARA - IBG, 2004). O rio Iguaçu tem suas nascentes na serra do Tinguá, a uma altitude de cerca de $1000 \mathrm{~m}$.

Possui uma extensão de aproximadamente 43 km e deságua na Baía de Guanabara. Seus principais afluentes são os rios: Tinguá, Pati e Capivari pela margem esquerda e Botas e Sarapuí, pela margem direita (GOVERNO DO ESTADO DO RIO DE JANEIRO, 1996). O relevo da bacia se caracteriza principalmente por duas unidades: a serra do Mar, onde se encontra o ponto culminante da bacia, o pico do Tinguá, (1600m), e a Baixada Fluminense. O clima é quente e úmido, com estação chuvosa no verão, temperatura média em torno de $22^{\circ} \mathrm{C}$ e precipitação média anual em torno de $1700 \mathrm{~mm}$ (GOVERNO DO ESTADO DO RIO DE JANEIRO, 1996) .

As perdas de terras por erosão representam significativas perdas de fertilidade dos solos acarretando diminuição na capacidade de produzir alimentos, aumento dos custos com adubos químicos e corretivos de acidez para compensar as perdas pela degradação. Pode-se citar também os impactos negativos sobre os cursos d'água, pela grande quantidade de sedimentos carreados por erosão, causando assoreamento do leito dos rios, aumento da carga de nutrientes e desequilíbrio das interações da cadeia alimentar aquática gerando enfim diminuição acelerada da qualidade das águas, das terras e, consequentemente, perda de qualidade de vida. No desenvolvimento de áreas urbanas, quando não há controle da erosão, a produção de sedimentos pode chegar à cerca de 380 toneladas por hectare (SERLA, 1996).

Em áreas urbanas, a erosão é resultante de diversos fatores, além dos naturais que são clima, tipo de solo, declividade do terreno e manejo da terra, outros tais como: traçado inadequado do sistema viário; falta de pavimentação, guias e sarjetas; deficiência dos sistemas de drenagem das águas pluviais e servidas; e expansão urbana descontrolada, com loteamentos em locais impróprios. Os efeitos são os mais variados e bastante extensivos. Dentre os danos comuns podemos citar os transtornos no tráfego das ruas, inundações por assoreamento de canais mal dimensionados ou sem manutenção, desvalorização imobiliária, perda de qualidade de vida e, muitas vezes, perdas materiais e humanas significativas. 
$\mathrm{Na}$ bacia do Iguaçu-Sarapuí, excluindo-se as áreas de florestas das serras do Tinguá e de Madureira, a bacia sofre processos erosivos significativos, tanto nas áreas rurais como urbanas. Em mais de 400 anos de ocupação, com sucessivos desmatamentos, uso agropastoril intensivo com técnicas de cultivo inadequadas, expansão urbana desordenada, cortes de morros para aterros e estradas e exploração mineral, dentre outros usos.

Estes fatores são agravados por uma estrutura administrativa fragmentada, incapaz de articular as ações integradas no âmbito municipal ou estadual, concorrendo para a diminuição da qualidade de vida dos habitantes da região.

As prefeituras, responsáveis pela gestão do uso do solo e pela implantação e manutenção da infraestrutura urbana de seus municípios, carecem de mecanismos, recursos humanos e materiais para levar a cabo suas atribuições. Os órgãos estaduais, afetados por fortes carências de recursos humanos, técnicos e financeiros, responsáveis pela gestão dos recursos hídricos, desenvolvem ações isoladas e demonstram dificuldades em articular ações conjuntas.

A ocupação na bacia concentrou-se na planície, nas áreas mais próximas às vias de acesso (rodovias e ferrovias) à metrópole, em terrenos planos, muitas vezes sujeitos a inundações periódicas. Em uma incursão pela área fica nítida a falta de planejamento, de adoção de critérios urbanísticos adequados e o desrespeito às normas e leis de parcelamento do solo. Muitos loteamentos foram implantados sem atendimento às normas técnicas e sem a infra- estrutura urbana necessária. Moradias situadas nas faixas de servidão de cursos d'água e nas estruturas de controle de cheias devem ser realocadas. As áreas destinadas para reassentamentos devem estar o mais próximo possível dos locais de origem das populações realocadas e outros critérios também devem ser considerados, tais como: condições de suporte geotécnico do terreno - esse aspecto tem grande influência no custo de execução de aterros; condições topográficas que favoreçam a implantação de micro drenagem, pavimentação e esgotamento sanitário; e a proximidade de infraestrutura urbana preexistente, como transportes, eletrificação, água e esgoto e serviços de saúde. (GOVERNO DO ESTADO DO RIO DE JANEIRO, 1996).

Um zoneamento de usos na bacia é uma medida fundamental para o desenvolvimento da região (implantação de estradas, indústrias, expansão urbana). Ações isoladas e desintegradas do contexto dos problemas na bacia hidrográfica são de pouca eficácia para o controle das inundações. De pouco adiantará, por exemplo, o município de Caxias realizar obras de drenagem, saneamento, reflorestamento no trecho da bacia que lhe pertence, se os municípios do trecho à montante continuarem lançando resíduos e sedimentos nos corpos d'água. Todas as ações de gestão de Recursos Hídricos somente terão eficácia se implantadas de acordo com um zoneamento ecológico-econômico para toda a bacia, articulado com as leis, planos e programas dos municípios pertencentes à mesma.

\section{PROCEDIMENTOS METODOLÓGICOS}

Da literatura técnica e das discussões com muitas organizações, está claro que muita confusão e falta de esclarecimento ainda persistem sobre as razões para coletar dados da qualidade de água. Em alguns casos, uma necessidade forte para um programa da qualidade de água é expressa, com pouca definição de finalidades e de objetivos do programa, exceto uma noção vaga de "saber a qualidade". Mais a mais, alguns programas de levantamento de dados bem projetados, quando baseados na aproximação usual de monitoramento padrões falham em não incluir recursos e projetos específicos para interpretar e analisar os dados coletados, RICKERT (1991). 
A falta de objetivos claros, e como consegui-los, resulta que em muitos órgãos governamentais ou privados são gastos recursos financeiros limitados em:

(a) coletando dados da qualidade de água que tem pouco ou nenhum significado em termos das possíveis fontes poluentes;

(b) emitindo relatórios que consistem meramente em tabelas contendo dados "crus" com quase nenhuma interpretação;

(c) em projetos que prestam pouca ou quase nenhuma atenção à representatividade dos dados produzidos;

Conforme será mostrado na tabela 1, são quatro principais razões para coletar dado sobre a qualidade da água. Elas devem fornecer informações para:

(a) alcançar objetivos sociais;

(b) dar suporte a análise de decisão regulatória;

(c) definir problemas emergentes ou existentes da qualidade da água;

(d) permitir o avanço da compreensão científica. Estes quatro itens são listados propositadamente nesta ordem, porque a sequência deve fluir em ambos os sentidos para que os objetivos sociais sejam atendidos.

Tabela 1

\begin{tabular}{|c|c|c|c|}
\hline Atingir Metas Sociais & $\begin{array}{l}\text { Subsidiar o Sistema de Análise de } \\
\text { Decisões sobre Outorgas de Uso }\end{array}$ & $\begin{array}{l}\text { Definir Problemas } \\
\text { Emergentes oi } \\
\text { Existentes de } \\
\text { Qualidade da Água } \\
\end{array}$ & $\begin{array}{l}\text { Avançar no Desenvolvimento } \\
\text { Científico e Tecnológico }\end{array}$ \\
\hline 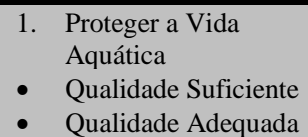 & $\begin{array}{l}\text { Desenvolver e melhorar o } \\
\text { planejamento, gerenciamento } \\
\text { e outorga de usos dos } \\
\text { recursos hídricos. }\end{array}$ & $\begin{array}{l}\text { 1.Temperatura } \\
\text { 2. Erosão/ } \\
\text { Assoreamento }\end{array}$ & $\begin{array}{l}\text { 1. Definir as condições naturais } \\
\text { de Q.A. (Blackground) }\end{array}$ \\
\hline $\begin{array}{ll}\text { 2. } & \text { Proteger à Saúde } \\
\text { Humana } \\
\text { - } \\
\text { Abastecimento } \\
\text { Público } \\
\text { - Recreação e Lazer } \\
\end{array}$ & $\begin{array}{ll}2 . & \text { Alocação de Recursos } \\
& \text { financeiros entre os } \\
& \text { diferentes problemas e } \\
& \text { programas de Q.A. }\end{array}$ & $\begin{array}{l}\text { 3. Salinização } \\
\text { 4. Qualidade Sanitária }\end{array}$ & $\begin{array}{l}\text { 2. Definir o Status atual das } \\
\text { condições de Q.A }\end{array}$ \\
\hline \multirow[t]{4}{*}{$\begin{array}{ll}\text { 3. } & \text { Proteger outras } \\
& \text { classes de Usos } \\
\text { - } & \text { Agricultura } \\
\text { - } & \text { Indústria } \\
\text { - } & \text { Estética }\end{array}$} & $\begin{array}{l}\text { 3. Estabelecer diretrizes, } \\
\text { padrões e critérios para os } \\
\text { efluentes e manutenção dos } \\
\text { usos da água. }\end{array}$ & $\begin{array}{l}\text { 5. Resíduos Orgânicos } \\
\text { Biodegradáveis } \\
\text { 6. Eutrofização }\end{array}$ & $\begin{array}{l}\text { 3. Definir mudanças ou } \\
\text { tendências na Q.A. }\end{array}$ \\
\hline & $\begin{array}{ll}\text { 4. } & \text { Garantir o cumprimento das } \\
\text { diretrizes, a obediência aos } \\
\text { padrões e critérios } \\
\text { estabelecidos para cada tipo } \\
\text { de efluente e uso específico } \\
\text { do solo. } \\
\end{array}$ & $\begin{array}{l}\text { 7. Acidificação } \\
\text { 8. Compostos Tóxicos }\end{array}$ & $\begin{array}{l}\text { 4. Identificar e avaliar as causas } \\
\text { dos problemas de Q.A. } \\
\text { - Naturais } \\
\text { - } \quad \text { Antrópicas }\end{array}$ \\
\hline & $\begin{array}{l}\text { 5. Delimitar a eficiência geral } \\
\text { do problema. }\end{array}$ & 9. Nitrato & $\begin{array}{l}\text { 5. Descobrir o fluxo, taxas e } \\
\text { fatores que regem o controle } \\
\text { dos processos químicos e } \\
\text { biológicos }\end{array}$ \\
\hline & $\begin{array}{l}\text { 6. Determinar a carga de } \\
\text { trabalho adicional de controle } \\
\text { de poluição }\end{array}$ & 10. Outros & \\
\hline
\end{tabular}

Razões para coletar dados de qualidade de água ( Fonte: RICKERT. 1991)

Ao analisar a tabela 1, podemos observar que ela foi desenvolvida para ajudar as organizações:

(a) efetuar decisões claras sobre as razões porque estão planejando ou conduzindo programas de qualidade da água;

(b) indicar claramente os objetivos e metas como uma base para projetar e executar os programas de qualidade da água, que tenham boa probabilidade de sucesso. 
O diagrama esquemático sugere que para preencher um conjunto tão complexo de necessidades de informação, irá requerer um processo que integre aproximações múltiplas, melhor que confiar meramente na aproximação padrão de estação fixa, amostragem fixa do intervalo do tempo. O processo integrado de aproximações múltiplas é a avaliação da qualidade de água (AQA), e a finalidade imediata é avançar na compreensão científica da qualidade da água. Infelizmente, a maioria das fontes de informação que citam as finalidades e os objetivos de programas de qualidade da água fornece somente uma parte deste retrato, com as razões específicas misturadas entre as diversas categorias. Alguns destes objetivos de monitoramento podem estar amarrados a razões específicas dentro das quatro categorias mencionadas, visto que outros são amplos ou confusos e parecem ter significado claro, mas de fato, possam ser definidos de forma muito diferente pelas diversas organizações.

$\mathrm{O}$ estudo de caso foi organizado da seguinte maneira: foram realizadas um total de 20 coletas de campo onde foram demarcados três pontos do rio "Iguassú": (P1- ponto um que está localizada na parte da nascente do rio, P2- ponto dois que situa-se na parte intermediária do rio e o P3-ponto três, trata-se do limite do município de Nova Iguaçu com Duque de Caxias. Foram estipulados alguns parâmetros para a realização da aferição da qualidade da água do rio, dos quais são: análise de macroinvertebrados que são considerados bioindicadores da qualidade da água, análise físico-química da água que atesta quais componentes estão presentes no material coletado, vazão do rio que é o volume de água do rio e análise ambiental que avalia a condição ecológica do rio e seu entorno.

Os parâmetros para aferir a qualidade da água e do grau de poluentes nela contida são: Parâmetros Gerais- Condições climáticas, Oxigênio dissolvido, Ph, Temperatura da Água, Temperatura do ar, DBO; Parâmetros Inorgânicos - Fósforo e Amônia. Cada ponto de coleta foi feito a coleta específica utilizando os parâmetros a serem observados nas laudas anteriores. A partir dos resultados coletados, foram elaborados gráficos que colaboram para uma melhor compreensão do estudo de caso.

Após a pesquisa de campo os dados foram analisados no laboratório de macroinvertebrados da entidade ambientalista Onda Verde, na qual realizo trabalhos acadêmicos envolvendo recursos hídricos, e a outra parte no laboratório de análise físicoquímico da mesma entidade. As coletas de campo foram realizadas durante o ano de 2014 e até o corrente ano 2015, sempre realizadas no início de uma estação do ano e ao seu final. As fotos abaixo nos permite ter uma melhor dimensão ao estudo de caso referido.

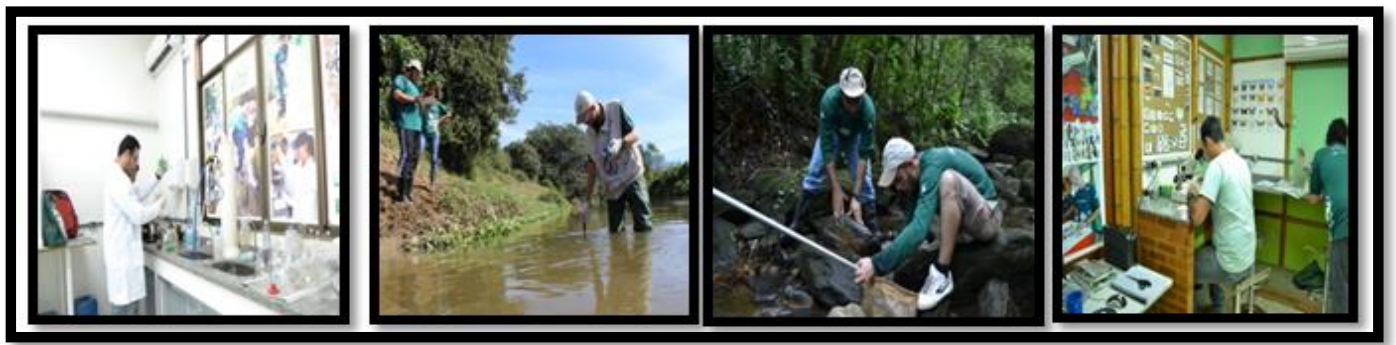

Procedimentos de campo e análise laboratorial

Basicamente, o monitoramento da água do rio "Iguassú" é realizado a partir de quatro formas de análise:

Físico-químicas e bacteriológicas da água;

$>$ Biológicas, utilizando os macroinvertebrados como Bioindicadores; 
Vazão, que é o volume de água do rio;

$>$ Ambiental, que avalia a condição ecológica do rio e seu entorno;

As análises físico-químicas foram realizadas através de coletas de amostras de água em campo e análise. São observados os seguintes parâmetros: temperatura da água, turbidez, pH, cloretos, oxigênio dissolvido, dureza, amônia e ortofosfato. Na imagem abaixo pode-se observar a análise físico-química da qualidade da água do rio "Iguassú", onde são analisadas amostras dos pontos 1,2 e 3 .

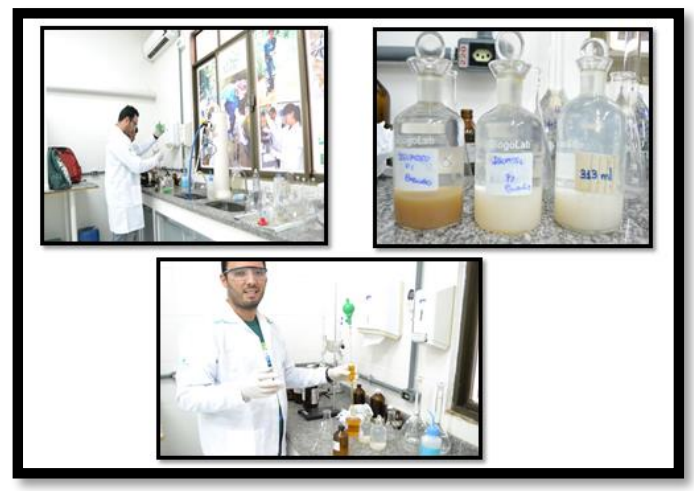

Para complementar as análises físico-químicas foi feito o monitoramento biológico ou biomonitoramento. Esta análise permite registrar um período maior do que apenas uma 'fotografia', funcionando com um 'filme'. Os animais e plantas que vivem nas águas funcionam como indicadores das condições do rio 24 horas por dia. Assim, se houver impacto ambiental, em qualquer horário do dia ou da noite, as espécies aquáticas serão afetadas, podendo ser usadas como indicadores da ocorrência do mesmo.

Nas imagens abaixo se pode verificar como é realizada a análise biológica. Primeiro a coleta nos pontos 1,2 e 3 do rio "Iguassú" e depois as amostras são levada para o laboratório MIB (Macroinvertebrados).

A vazão é a medida estimada do volume de água que passa no rio em um determinado tempo (geralmente medido por mil litros por segundo, ou tecnicamente, $\mathrm{m}^{3} / \mathrm{s}$ ). É composta por três dimensões, largura média $\mathrm{X}$ profundidade média $\mathrm{X}$ velocidade média da correnteza.

O rio é mais do que somente a água. Tudo o que cerca um rio influencia na sua qualidade. Nestas análises, avaliamos a condição ecológica do rio e seu entorno através da observação do tipo de sedimento e grau de sedimentação do fundo do rio, da disponibilidade de folhas e pedras para animais aquáticos, do tamanho e condição das matas ciliares entre outros como pode-se observar na imagem abaixo.

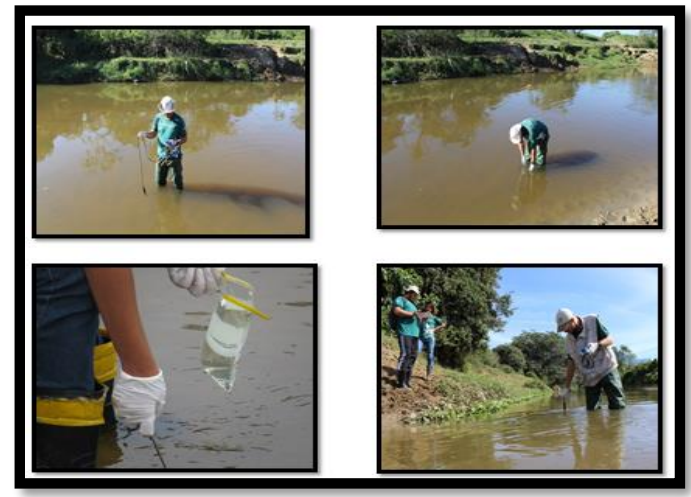



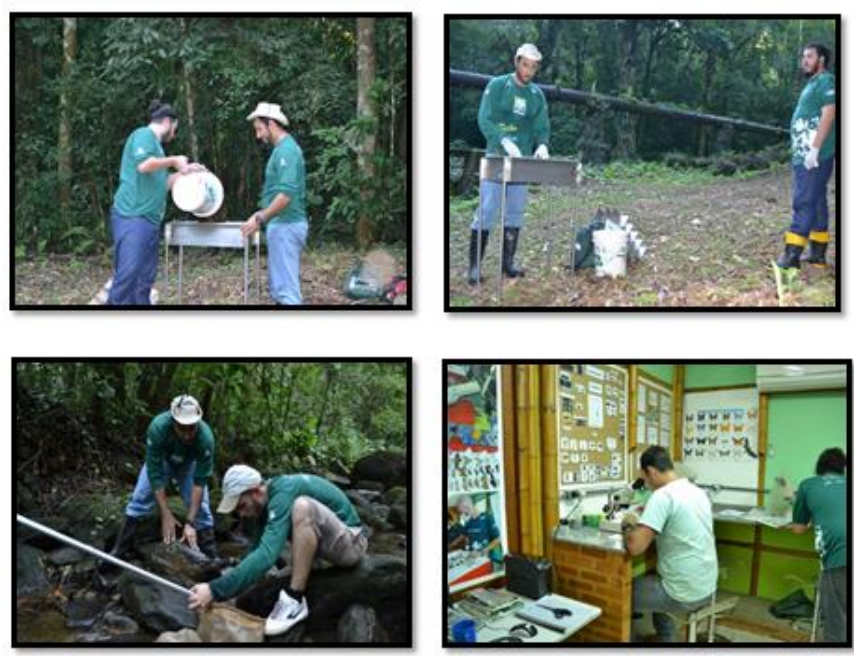

A medida mais eficaz de controle da poluição da água é a implantação de sistemas de coleta e tratamento de esgotos domésticos e industriais. Com os mesmos, evita-se que despejos brutos sejam lançados nos corpos d'água, poluindo-os. A partir dos dados coletados em campo somados aos dados do laboratório, obtiveram-se os seguintes resultados:

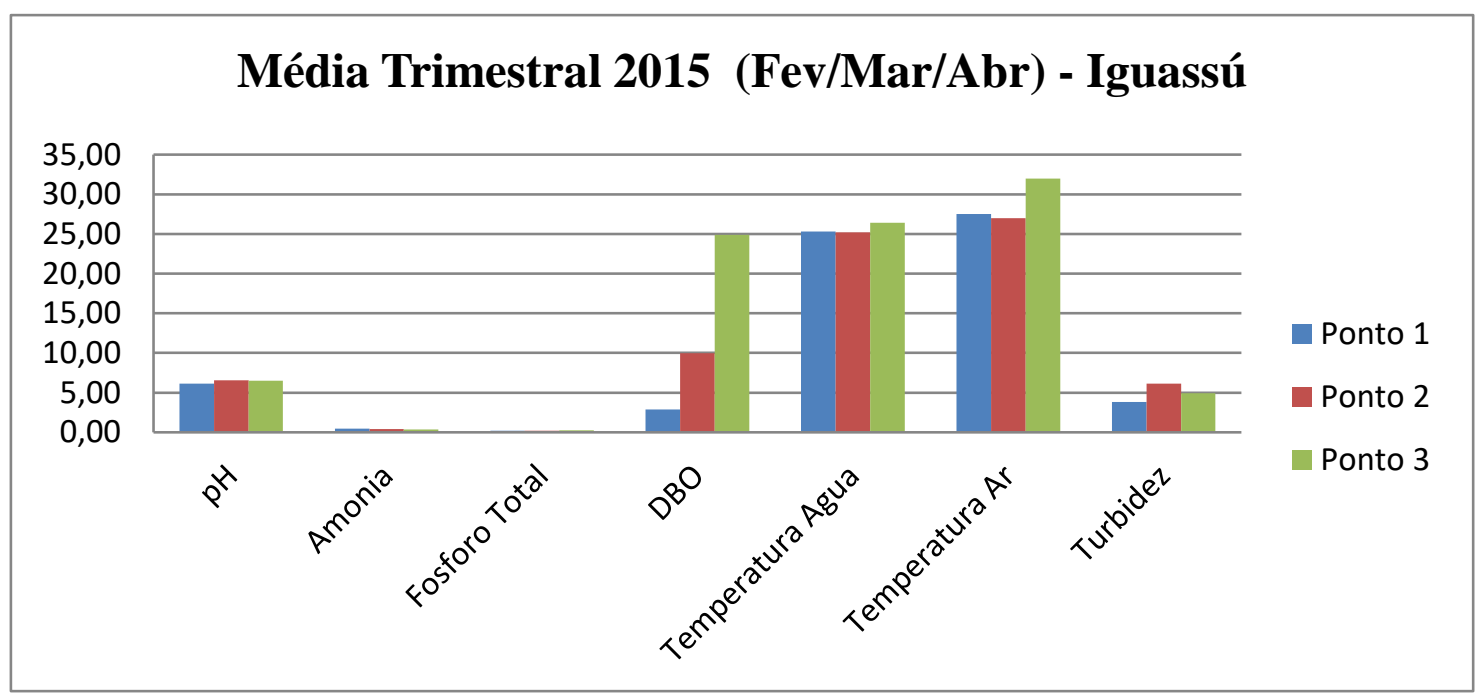



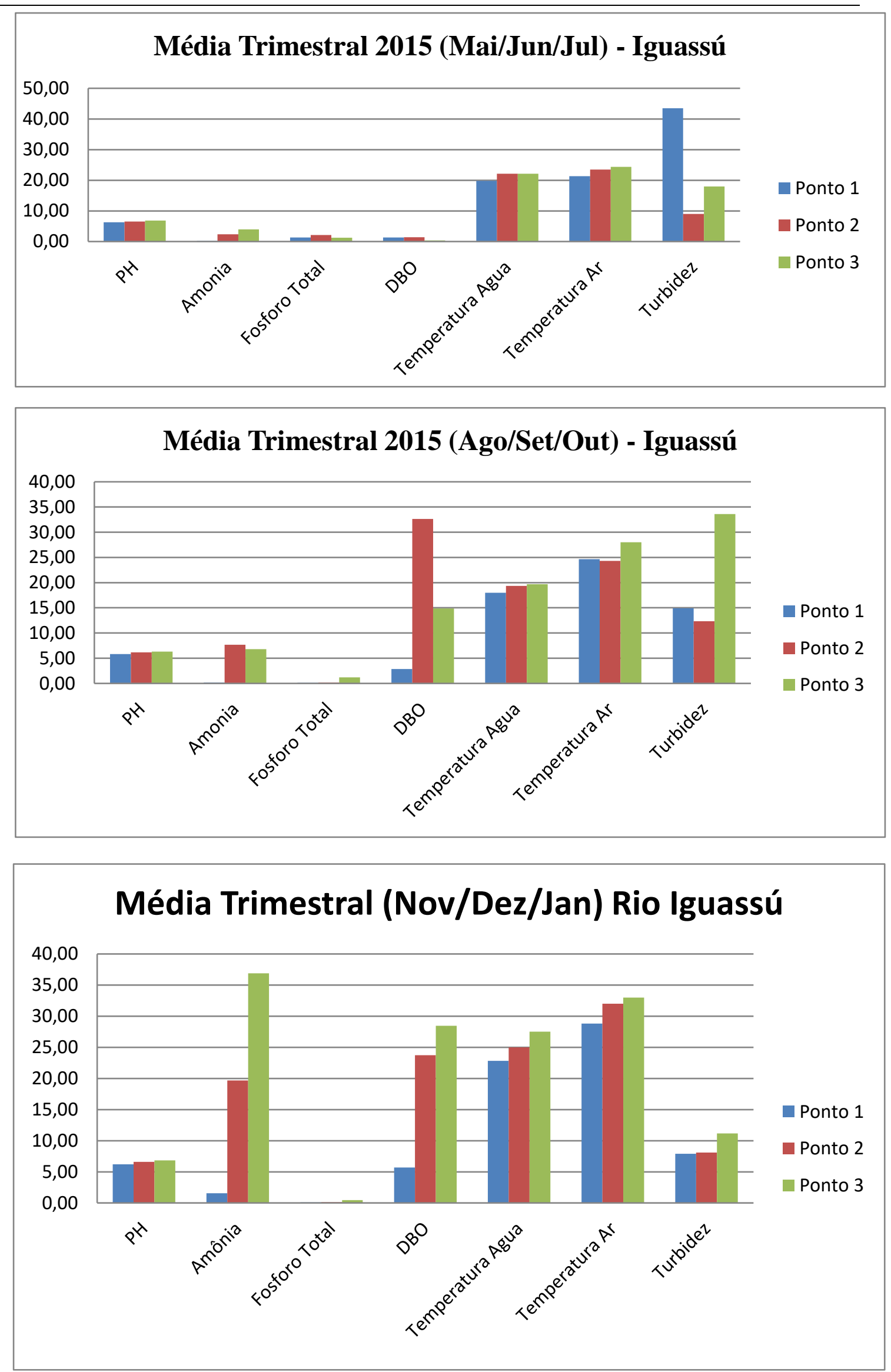
Na falta de sistemas coletivos de esgotamento, têm sido usadas soluções tipo fossa/sumidouro, as quais, embora, algumas vezes, apresentem resultados satisfatórios, podem se tornar fontes de poluição de mananciais subterrâneos e superficiais. As soluções coletivas são mais eficazes que as individuais. Ao observar os gráficos que foram elaborados com base nãos ados gerados pelo processo de coleta de amostras da água do rio Iguaçu, podemos observar que nos meses referente ao verão, houve um aumento significativo amônia. Fato este que pode ser explicado devido a presença de pequenas e médias propriedades policultoras localizadas na altura do ponto $2(\mathrm{P} 2)$ do rio Iguaçu, ode estas utilizam fertilizantes para melhorar a produção de suas culturas e também no tratamento de piscinas que utilizam esse composto químico para realizar a limpeza das mesmas.

$\mathrm{Na}$ implantação de sistemas de coleta e tratamento de esgotos, deve-se escolher criteriosamente os corpos receptores para os efluentes tratados, em função de sua capacidade de receber a carga poluidora, bem como da qualidade necessária aos seus usos. O grau de tratamento a ser aplicado aos esgotos dependerá das capacidades de depuração dos corpos d'água receptores. É importante considerar, nessa análise, os pontos de tomadas de água e os fins a que a mesma se destina.

São vários os processos de tratamento, os quais são utilizados em função da composição do esgoto e das características que se desejam para o efluente da estação depuradora, as quais dependem da capacidade do corpo receptor de receber carga poluidora. e dos usos da água a jusante do local de lançamento.

O entendimento das fontes potenciais de poluentes é de fundamental importância quando se estuda os impactos do lançamento dos escoamentos. A acumulação de vários poluentes dentro da área da bacia pode ser atribuída a diversas fontes e os efeitos individuais são de difícil separação. Todavia, o conhecimento qualitativo das prováveis fontes possibilita ao investigador a se concentrar nas áreas problemáticas e avaliar dispositivos de controle que podem ser usados para desviar cargas adversas antes que elas atinjam o sistema de drenagem.

De forma genérica, a poluição das águas decorre da adição de substâncias ou de formas de energia que, diretamente ou indiretamente, alterem as características físicas e químicas do corpo d'água de uma maneira tal, que prejudique a utilização das suas águas para usos benéficos. Torna-se importante ressaltar a existência de duas formas distintas, pelas quais as águas poluídas atingem um determinado corpo receptor: (a)fontes pontuais e (b) fontes não- pontuais ou fontes difusas.

A primeira, denominada fonte ou poluição pontual, refere-se, como o próprio nome esclarece, à poluição decorrente de ações modificadoras localizadas. É o caso, por exemplo, da desembocadura de um rio, de efluentes de uma estação de tratamento de esgotos domésticos ou industriais, ou mesmo, a saída de um tronco coletor de esgotos domésticos sem tratamento, ou ainda a saída no mar de um emissário submarino.

A segunda, denominada poluição difusa, se dá pela ação das águas da chuva ao lavarem e transportarem a poluição nas suas diversas formas espalhada sobre a superfície do terreno (urbano ou rural) para os corpos receptores. A poluição difusa alcança os rios, lagoas, baías, etc., distribuída ao longo das margens, não se concentrando em um único local como é o caso da poluição pontual. A origem da poluição difusa é bastante diversificada, sendo que contribuem: a abrasão e o desgaste das ruas pelos veículos, lixo acumulado nas ruas e calçadas, resíduos orgânicos de pássaros e animais domésticos, atividades de construção, resíduos de combustível, óleos e graxas deixados por veículos, poluentes do ar, etc. Os principais poluentes que são assim carreados são sedimentos, matéria orgânica, bactérias, metais como cobre, zinco, manganês, ferro e chumbo, hidrocarbonetos provenientes do petróleo, tóxicos, como os pesticidas, e os poluentes do 
ar que se depositam sobre as superfícies. Eventos de precipitação podem elevar as concentrações de metais tóxicos no corpo receptor até a níveis agudos, ELLIS (1986).

A principal razão de se promover um tratamento das águas pluviais é a redução dos impactos adversos sobre os corpos receptores. O problema da gestão da contaminação de águas no Brasil é recente e os dados estatísticos apontam para uma demanda crescente deste recurso, por exemplo, na Grande São Paulo, por exemplo, 95\% das indústrias, hospitais, hotéis e condomínios têm poços de captação subterrânea de água. Não obstante à crescente importância alcançada como fonte de abastecimento público, predomina a abordagem extrativista, com base apenas nas experiências que estão sendo conduzidas em outros países ou regiões, cujas realidades hidrogeológicas, sociais, econômicas e culturais são por vezes muito diferentes.

No limiar do século XXI, a humanidade vem se defrontando com uma série de problemas globais - ambientais, financeiros, econômicos, sociais e de mercado. Neste quadro, as preocupações com o ambiente, em geral, e com a água, em particular, adquirem especial importância, pois as demandas estão se tornando cada vez maiores, sob o impacto do crescimento acelerado da população e do maior uso da água, imposto pelos padrões de conforto e bem-estar da vida moderna. Entretanto, a qualidade da água da Terra - rios, lagos naturais e represas, em particular - dos ecossistemas e da vida, em geral, vem sendo degradada de uma maneira alarmante, e esse processo pode logo ser irreversível, sobretudo nas áreas mais densamente povoadas dos países emergentes, como o Brasil.

Com as crescentes pressões humanas sobre os ambientes naturais, a Educação Ambiental tem se tornado cada vez mais importante como meio de buscar apoio e participação dos diversos segmentos da sociedade para a conservação e melhoria da qualidade de vida. A Educação Ambiental propicia o aumento de conhecimentos, mudanças de valores e o aperfeiçoamento de habilidades, que são condições básicas para que o ser humano assuma atitudes e comportamentos que estejam em harmonia com o meio ambiente.

A preocupação oficial com a necessidade de um trabalho educativo que procurasse sensibilizar as pessoas para as questões ambientais, surgiu em 1972, na Conferência sobre Meio Ambiente Humano, realizado pela ONU, em Estocolmo. A conferência gerou a Declaração sobre o Meio Ambiente Humano e teve como objetivo chamar a atenção dos governos para a adoção de novas políticas ambientais, entre elas um Programa de Educação Ambiental, visando a educar o cidadão para a compreensão e o combate à crise ambiental no mundo.

\section{CONCLUSÃO}

O mundo enfrenta um rápido aumento do conjunto de desafios à qualidade da água, contudo, ainda existem soluções efetivas que podem ser implementadas. Existem diversas escalas de soluções para os problemas da qualidade da água. A situação da qualidade da água e os regimes regulatórios que protegem esta qualidade variam muito nos diferentes países do mundo. Em regiões que carecem de políticas nacionais específicas ou de fiscalização adequada, sistemas de proteção em nível subnacional ou de bacia hidrográfica podem apresentar alternativa efetiva. Soluções de vizinhança ou domiciliares podem ser especialmente efetivas em lugares onde os serviços municipais de tratamento de água potável e de coleta e tratamento de esgoto inexistem ou não atendem a parcelas significativas da comunidade. Ademais, a demanda comunitária por regulação, fiscalização e incentivos para a melhoria da qualidade da água pode ser útil em todas essas escalas. 
Em nível domiciliar, o tratamento efetivo da água potável pode ser de grande importância para melhorar a saúde humana e dos ecossistemas. Quando se trata das discussões relacionadas à qualidade da água, a bacia hidrográfica é considerada a unidade funcional mais importante, pois reúne todas as diferentes fontes, usuários e poluentes. Em cada país, os regulamentos nacionais, os financiamentos, a padronização e o monitoramento podem promover avanços das reformas que devem ser empreendidas localmente. Ao nível internacional, o aumento da atenção dedicada à questão da qualidade da água, o desenvolvimento de diretrizes e normas, bem como a promoção de intercâmbios de lições aprendidas e experiências bem-sucedidas podem servir de apoio a iniciativas locais.

O envolvimento desigual de homens e mulheres em situação de vulnerabilidade tem prejudicado alguns programas e projetos direcionados à garantia da sustentabilidade da gestão de recursos hídricos. As relações de poder muitas vezes deixam as mulheres em posição de desvantagem. A aplicação de uma análise de gênero abrangente ajuda a assegurar o sucesso na definição de legislação, políticas e programas orientados à promoção da melhoria da qualidade da água e à distribuição equitativa de recursos hídricos.

Um dos princípios básicos da Gestão Integrada de Recursos Hídricos é que as mulheres devem ser reconhecidas como atores centrais no fornecimento, na gestão e na proteção da água. Em vista do papel tradicional das mulheres na gestão de recursos hídricos, seus conhecimentos e habilidades devem ser levadas em consideração nos processos de planejamento e execução de ações.

Ações educativas, de conscientização e de proteção para melhorar a qualidade da água são mais bem-sucedidas quando articulam preocupações quanto à qualidade da água, às questões, mais interessam as pessoas; em outras palavras, é importante relacionar o conceito abstrato de qualidade da água com assuntos concretos que realmente atingem as pessoas. $\mathrm{O}$ tema de qualidade da água precisa se tornar relevante nas vidas das pessoas. Mudar comportamentos, convencer formuladores de políticas e incitar a mídia a dar cobertura ao tema exige bastante atenção às diversas maneiras em que a qualidade da água intercede com as necessidades e os valores do ser humano. 


\section{REFERÊNCIAS BIBLIOGRÁFICAS}

DRISCOLL, E .D., SHELLEY, P .E., E.W. STRECKER, 1990, "Pollutant Loadings and Impacts from Storm water Runoff', Volume III: Analytic al Investigation and Research Report. FHWA-RD-88-008, Federal Highway Administration.

DRISCOLL, E.D., SHELLEY, P.E. STRECKER, E.W., 1990, Pollutant Loadings and Impacts from Highway Storm water Runoff .Analytical Investigation and Research Report, FHWA-RD-88-008, Vol. III.

INSTITUTO BAÍA DE GUANABARA (IBG), 2004, disponível em http://www.baiadeguanabara.org.br, acesso em 1/11/2014

GOVERNO DO ESTADO DO RIO DE JANEIRO, Secretaria de Estado de Meio Ambiente e Projetos Especiais, Fundação Superintendência Estadual de Rios e LagoasSERLA, convênio SERLA - COPPE/UFRJ, Plano Diretor de Recursos Hídricos da Bacia do Rio Iguaçu: ênfase: Controle de Inundações, Documento de Projeto, IG - RE - 010 R0, outubro de 1994

, convênio SERLA -COPPE/UFRJ, financiamento CEF/BIRD 2975 - br, projeto PNUD BRA - 93/022, Plano Diretor de Recursos Hídricos da Bacia do Rio Iguaçu -Sarapuí Ênfase: Controle de Inundações, Relatório Final Vol. 1, Rio de Janeiro, 1996.

RICKERT, D.A., 1991, Water Quality Assessment: A New Concept for Measuring The Quality of Surface and Ground Water, Technical Reports in Hydrology and Water Resources No.34, World Meteorological Organization, August, pp. 38 -79.

ELLIS, J.B., 1986, "Pollutional Aspects of Urban Runoff”. In: Urban Runoff Pollution ,Eds. H.J. Marsalek and M. Desbordes, NATA ASI Series, Series G: Ecological Sciences, Vol. 10, Springer-Verlag, Berlin. 